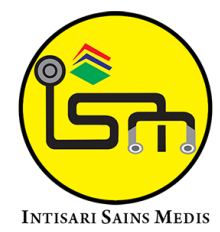

Published by Intisari Sains Medis

\title{
Pengaruh lama paparan trauma listrik terhadap sistem saraf traktus gastrointestinal pada tikus Wistar galur murni
}

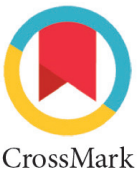

CrossMark

\author{
Slamet Rahardja ${ }^{1 *}$, Adeodatus Yuda Handaya ${ }^{2}$, Agus Barmawi ${ }^{2}$
}

\section{ABSTRACT}

Background: Electrical trauma can cause injury to the body tissues it passes through, causing death. The injury is part of the process of cell damage, including the digestive organs. This study aims to determine the effect of the duration of electrical trauma on the nervous system of the gastrointestinal tract histopathologically. Methods: This study was experimental with the research subjects were 24 pure strain Wistar rats, which were divided into 4 groups. The first group is the control group (K) without treatment. Then, group (X) was exposed to electricity for 15 seconds, group (Y) was given exposure for 30 seconds, and group (Z) was exposed to 60 seconds. From the preparations, the number of nerve cells was counted. Data were analyzed with SPSS version 20 for Windows.

Results: Therewas a significant effect on the duration of electrical trauma on the number of the gastrointestinal tract nervous system histopathologically $(p<0.05)$. In the control group (K), the number of nerve cells for the stomach was $91.33 \pm 0.60$, followed by the ileum (89.50 \pm 07.09$)$, and colon (94.33 \pm 6.18$)$. In group $(\mathrm{X})$, the number of nerve cells in the stomach was $79.50 \pm 11.823$, followed by the ileum $(62.00 \pm 15.31)$, and colon $(78.83 \pm 5.04)$. In group (Y), the number of nerve cells for gastric was $45.33 \pm 7.66$, followed

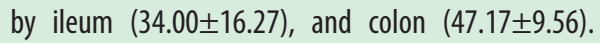
Meanwhile, in the group (Z), the number of nerve cells for the stomach was $2.40 \pm 0.55$, followed by the ileum (1.40 \pm 1.52$)$, and colon (1.80 \pm 1.10$)$. Thus, there was a significant difference between the study groups $(p<0.001)$.

Conclusion: The duration of electrical trauma significantly affects the number of the gastrointestinal tract nervous system histopathologically.

Keywords: Electrical Trauma, Duration of Exposure, Gastrointestinal Tract Nervous System.

Cite This Article: Rahardja, S., Handaya, A.Y., Barmawi, A. 2021. Pengaruh lama paparan trauma listrik terhadap sistem saraf traktus gastrointestinal pada tikus Wistar galur murni. Intisari Sains Medis 12(2): 504-507. D0I: 10.15562/ism.v12i2.1001

${ }^{1}$ Trainee Bedah Digestif, Fakultas Kedokteran Universitas Gadjah Mada, RSUP Dr Sardjito Yogyakarta, Indonesia;

${ }^{2}$ Konsultan Bedah Digestif, Fakultas Kedokteran Universitas Gadjah Mada, RSUP Dr Sardjito Yogyakarta, Indonesia;

\section{*Korespondensi:}

Slamet Rahardja;

Trainee Bedah Digestif, Fakultas Kedokteran Universitas Gadjah Mada, RSUP Dr Sardjito Yogyakarta, Indonesia;

adeng.slametrahardja@gmail.com

Diterima: 13-03-2021

Disetujui: 20-07-2021

Diterbitkan: 30-07-2021

\section{ABSTRAK}

Latar Belakang: Trauma listrik dapat menimbulkan perlukaan pada jaringan tubuh yang dilewatinya hingga menyebabkan kematian. Perlukaan tersebut merupakan bagian dari proses kerusakan sel, termasuk pada organ digestif. Penelitian ini bertujuan untuk mengetahui pengaruh lama paparan trauma listrik terhadap sistem saraf traktus gastrointestinal secara histopatologi.

Metode: Penelitian ini bersifat eksperimental dengan subyek penelitian adalah 24 ekor tikus Wistar galur murni, yang terbagi dalam 4 kelompok. Kelompok pertama merupakan kelompok kontrol (K) tanpa perlakuan. Kelompok $(X)$ diberi paparan listrik selama 15 detik, kelompok (Y) diberi paparan selama 30 detik, dan kelompok (Z) diberi paparan selama 60 detik. Dari preparat, dilakukan penghitungan terhadap jumlah sel saraf. Data dianalisis dengan SPSS versi 20 untuk
Windows.

Hasil: Terdapat pengaruh yang bermakna pada lama trauma listrik terhadap jumlah sistem saraf traktus gastrointestinal secara histopatologis $(p<0,05)$. Pada kelompok kontrol (K), jumlah sel saraf untuk gaster adalah 91,33 $\pm 0,60$, diikuti dengan ileum $(89,50 \pm 07,09)$, dan kolon $(94,33 \pm 6,18)$. Pada kelompok $(X)$, jumlah sel saraf pada gaster adalah $79,50 \pm 11,823$, diikuti dengan ileum $(62,00 \pm 15,31)$, dan kolon (78.83 \pm 5.04$)$. Pada kelompok (Y), jumlah sel saraf untuk gaster adalah $45,33 \pm 7,66$, diikuti dengan ileum $(34,00 \pm 16,27)$, dan kolon $(47,17 \pm 9,56)$. Sedangkan pada kelompok (Z), jumlah sel saraf untuk gaster adalah $2,40 \pm 0,55$, diikuti dengan ileum $(1,40 \pm 1,52)$, dan kolon $(1,80 \pm 1,10)$. Didapatkan perbedaan bermakna antara kelompok penelitian $(p<0,001)$. 
Kesimpulan: Lama trauma listrik memiliki pengaruh gastrointestinal secara histopatologi. secara bermakna terhadap jumlah sistem saraf traktus

Kata kunci: Trauma Listrik, Lama Paparan, Sistem Saraf Traktus Gastrointestinal.

Sitasi Artikel ini: Rahardja, S., Handaya, A.Y., Barmawi, A. 2021. Pengaruh lama paparan trauma listrik terhadap sistem saraf traktus gastrointestinal pada tikus Wistar galur murni. Intisari Sains Medis 12(2): 504-507. D0l: 10.15562/ism.v12i2.1001

\section{PENDAHULUAN}

Trauma listrik dapat menyebabkan luka yang menimbulkan kerusakan jaringan tubuh akibat aliran arus listrik yang melintasi tubuh hingga kematian. ${ }^{1}$ Klasifikasi trauma listrik berdasarkan besaran tegangan dibagi low-voltage injury (LVI), di bawah 1000 volts dan high-voltage injury (HVI), di atas 1000 volts. ${ }^{1}$ Insiden trauma listrik cukup jarang hanya 0,04-5 $\%$ dari kasus luka bakar yang masuk ke unit luka bakar. ${ }^{1,2}$

Penelitian kasus luka bakar akibat trauma listrik di Korea Selatan menunjukkan bahwa kasus yang mengenai kaum pria lebih banyak daripada wanita dengan perbandingan 13,5 berbanding 1, dimana dengan rerata usia adalah 33,4 tahun. ${ }^{2}$ Sebagian besar kasus trauma listrik berhubungan dengan jenis pekerjaan. ${ }^{3}$

Derajat keparahan kerusakan jaringan tubuh manusia akibat trauma listrik dipengaruhi oleh jenis sirkuit listrik, lama waktu kontak tubuh dengan listrik, tahanan dalam jaringan tubuh, besarnya tegangan listrik, kuat arus listrik dan sifat konduktor media. ${ }^{4}$ Paparan listrik yang masuk ke dalam tubuh akan menimbulkan kerusakan terutama terjadi pada jaringan saraf, pembuluh darah dan otot. Paparan listrik dapat mengakibatkan nekrosis berupa koagulasi, kerusakan pembuluh darah dan kematian sel saraf. ${ }^{4}$

Pada sistem pencernaan atau organ digestif menunjukkan tidak ada perbedaan yang bermakna pada komplikasi yang terjadi setelah terpapar listrik. ${ }^{5}$ Namun, beberapa laporan kasus menunjukkan sebaliknya adanya dampak trauma listrik pada traktus gastrointestinal berupa ileus paralitik maupun perforasi pada kolon dan usus halus. ${ }^{6,7}$ Fungsi sistem gastrointestinal sendiri di samping dipengaruhi oleh mekanisme hormonal dan enzimatik dalam menjalankan fungsinya, juga dipengaruhi oleh sistem persarafan melalui pleksus Meisneri dan Aurbachi di sepanjang lapisan submukosa maupun otot, yang berperan dalam gerakan peristaltik maupun mencampur berbagai jenis makanan. ${ }^{8}$

Fungsi gastrointestinal sendiri di samping dipengaruhi oleh mekanisme hormonal dan enzimatik dalam menjalankan fungsinya, juga dipengaruhi oleh sistem persarafan melalui pleksus Meisneri dan Aurbachi di sepanjang lapisan submukosa maupun otot, yang berperan dalam gerakan peristaltik maupun mencampur. ${ }^{8,9}$ Gerakan usus tampaknya diatur oleh usus itu sendiri dan tidak melalui Sistem Saraf Pusat (SSP) dengan bantuan neurotransmiter serotonin, sehingga dikenal sebagai second brain. ${ }^{10-13}$ Sel-sel saraf akan rusak karioptosis dan sulit beregenerasi akibat terpapar arus listrik, seperti halnya jaringan saraf di otak. ${ }^{9}$ Gambaran histopatologis dalam menilai kerusakan jaringan tubuh manusia akibat trauma listrik merupakan penilaian yang bersifat objektif dibandingkan kerusakan yang dilihat secara klinis. ${ }^{14-16}$

Besarnya pengaruh listrik pada jaringan tubuh tergantung dari besarnya tegangan (voltage), kuatnya arus (ampere), besarnya tahanan (resistensi), lamanya kontak, dan luasnya daerah yang terkena kontak. ${ }^{17}$ Berdasarkan pada pemaparan di atas, maka penelitian ini bertujuan untuk mengetahui pengaruh trauma listrik terhadap gambaran sistem saraf traktus gastrointestinal secara histopatologi.

\section{METODE}

Penelitian ini menggunakan hewan coba tikus Wistar galur murni jantan berusia 3 bulan dengan berat badan 200 gram, diperoleh dari Laboratorium Pusat Antar Universitas (PAU) Universitas Gadjah Mada sebanyak 24 ekor. Pakan tikus berupa pelet dan air minum diberikan setiap hari secara ad libitum. Bahan-bahan yang diperlukan dalam penelitian ini adalah bahan-bahan pembuat preparat histologis, dengan teknik blok parafin dengan pewarnaan cresyl violet. Alatalat yang digunakan adalah mikroskop cahaya, kamera digital, alat bedah minor, alat pembuatan sediaan histologis serta peralatan listrik berupa AC variable power supply.

Rancangan penelitian ini adalah eksperimental sederhana posttest-onlycontrol design. Subjek dibagi menjadi empat kelompok yang dipilih secara random, yaitu kelompok kontrol (K), kelompok X, kelompok Y, dan kelompok Z. Masing-masing kelompok terdiri atas 6 ekor tikus.

Setelah tikus dipilah-pilah sesuai kelompoknya, secara bertahap tikus diambil kemudian dimasukkan ke dalam tabung paralon ukuran panjang $30 \mathrm{~cm}$ dengan diameter $7 \mathrm{~cm}$, yang telah dimodifikasi sedemikian rupa untuk memfiksasi tikus. Pada kedua ujung tabung terdapat kabel elektrode yang berasal dari AC variable power supply. Satu elektrode dipasangkan pada kulit kepala sisi anterior atas, sedangkan elektrode lainnya dipasang pada ekor. Dalam posisi tikus terfiksasi, selanjutnya dilakukan penghantaran listrik tegangan 220 volt dengan kuat arus 0,5 Ampere. Kelompok X diberi paparan listrik dengan durasi 15 detik, kelompok Y selama 30 detik dan kelompok Z selama 60 detik. Selanjutnya dilakukan operasi untuk diambil organ gaster hingga kolon secara utuh dan kemudian dimasukkan dalam tabung yang berisi cairan pengawet buffer formalin $10 \%$. Direndam selama 2 hari, selanjutnya jaringan dipilah bagian gaster, ileum dan kolon. Setelah itu dilakukan proses pembuatan preparat histologi dengan pewarnaan cresyl violet. Inti sel akan terwarnai biru-transparan. 
Jumlah sel saraf yang berbentuk piramidal dihitung berdasarkan terlihatnya inti sel. Sediaan dilihat menggunakan mikroskop cahaya pembesaran $400 \mathrm{x}$, dan dinyatakan dalam jumlah rerata per lapang pandang.

Perbedaan jumlah sel piramidal antar keempat kelompok (skala rasio) diuji dengan uji Shapiro-Wilk kemudian dilanjutkan uji Post-Hoc dengan analisis Mann-Whitney. Pengambilan keputusan adanya perbedaan bermakna jika nilai probabilitas $\mathrm{p}<0,05$. Data dianalisis dengan piranti lunak SPSS versi 20 untuk Windows.

\section{HASIL}

Setelah dilakukan perhitungan jumlah sel piramidal pada gaster, ileum dan kolon pada masing-masing preparat, didapatkan hasil rerata sel per lapang pandang dimana pada gaster dan ileum data terdistribusi dengan tidak normal $(\mathrm{p}<0,05)$ dengan analisis Shapiro-Wilk, sehingga diperlukan analisa lanjutan untuk melihat perbedaan 4 kelompok dengan memakai NonPar Kruskall-Wallis (Tabel 1).

Hasil penelitian ini menunjukkan bahwa jumlah sel saraf yang dinilai secara histopatologi menunjukkan nilai paling rendah pada kelompok $Z$ baik pada organ faster $(2,40 \pm 0,55)$, ileum $(1,40 \pm 0,52)$, dan kolon $(1,80 \pm 1,10)$. Dari hasil analisa lanjutan dengan NonPar Kruskall-Wallis, didapatkan perbedaan yang bermakna pada rerata kelompok perlakuan terhadap gaster, ileum dan kolon $(\mathrm{p}<0,001)$ (Tabel 1). Sedangkan, pada analisis Post-Hoc, evaluasi jumlah sel saraf pada gaster kelompok kontrol dengan kelompok 2 secara statistik tidak ada perbedaan yang bermakna $(\mathrm{p}=0.132)$. Sedangkan pada kelompok lainnya diketahui berbeda bermakna secara statistik baik pada gaster, ileum dan kolon $(\mathrm{p}<0,05)$ (Tabel 1).

\section{PEMBAHASAN}

Pada penelitian ini didapat hasil terdapat perbedaan bermakna paparan listrik dengan jumlah sel saraf pada traktus gastrointestinal ( $\mathrm{Y}$ dan $\mathrm{Z}$ ), pengecualian pada gaster kelompok kontrol dengan kelompok X (15 detik). Hal ini menunjukkan bahwa dampak trauma listrik yang merusak organ

Tabel 1. Analisis beda rerata jumlah sel saraf berdasarkan kelompok lama durasi dan organ.

\begin{tabular}{cccc}
\hline Kelompok Penelitian & Gaster & Ileum & Kolon \\
\hline Kontrol (rerata \pm SB) & $91,33 \pm 0,60$ & $89,50 \pm 07,09$ & $94,33 \pm 6,18$ \\
Kelompok X (rerata \pm SB) & $79,50 \pm 11,82$ & $62,00 \pm 15,31$ & $78,83 \pm 5,04$ \\
Kelompok Y (rerata \pm SB) & $45,33 \pm 7,66$ & $34,00 \pm 16,27$ & $47,17 \pm 9,56$ \\
Kelompok Z (rerata \pm SB) & $2,40 \pm 0,55$ & $1,40 \pm 0,52$ & $1,80 \pm 1,10$ \\
P1 & $<0,001^{\star}$ & $<0,001^{\star}$ & $<0,001^{\star}$ \\
P2 & 0,132 & $<0,05^{\star}$ & $<0,05^{\star}$
\end{tabular}

P1: NonPar Kruskall-Wallis; P2: Analisis Post-Hoc Mann-Whitney; ${ }^{\star}$ Berbeda bermakna secara statistik apabila nilai-p kurang dari 0,05.

tubuh mencapai jaringan saraf di saluran pencernaan.,18 Ini juga menunjukkan bahwa degradasi jumlah sel-sel saraf secara kuantitatif pada traktus gastrointestinal oleh trauma listrik bertegangan tinggi sama dengan jaringan susunan saraf pusat seperti halnya pengaruh kerusakan akibat bahan kimia seperti halnya nekrosis akibat pengaruh etanol dan formalin. ${ }^{19,20}$ Mekanisme hantaran dari luka masuk (input) hingga luka keluar (output) belum bias diterangkan pada penelitian ini.. ${ }^{21}$ Demikian pula mekanisme degradasinya sendiri dimungkinkan sama dengan kerusakan otak yang dimulai dari proses piknosis, karioreksis, kariolisis hingga nekrotik. ${ }^{20,21}$

Pengecualian hasil pada gaster kelompok Kontrol dengan kelompok 15 detik dimungkinkan adanya kesalahan saat proses pemotongan jaringan, pembuatan preparat maupun pewarnaan cresyl violet yang tidak tepat.

Hasil penelitian ini juga menunjukkan bahwa lama durasi paparan akan mempengaruhi kerusakan sel-sel saraf traktus gastrointestinal. Pengaruh ini bias menjawab mengapa pada kasus-kasus luka bakar akibat trauma listrik bertegangan tinggi ditemukan gejala klinis paralitik. ${ }^{6}$ Di samping faktor-faktor organik lain, seperti gangguan elektrolit, adanya penurunan jumlah sel-sel saraf yang belum rusak diperkirakan kurang cukup adekuat untuk merangsang pergerakan peristaltik usus. Di samping itu, dasar penilaian pada penelitian ini adalah pada jumlah sel saraf yang masih utuh, bukan yang rusak (nekrosis), sehingga memungkinkan kerusakan sel yang terjadi masih pada level karioreksis ataupun kariolisis yang bersifat reversibel. Namun demikian, perlu dilakukan penelitian lanjutan untuk memastikan keterkaitan gerakan peristaltik dengan trauma listrik bertegangan tinggi dengan pengamatan langsung terhadap motilitas usus menggunakan radioisotop.

Adanya keterkaitan laporan kasus perforasi usus baik pada ileum dan kolon pada kasus luka bakar akibat trauma listrik bertegangan tinggi belum bisa dijelaskan melalui penelitian ini. ${ }^{22,23} \mathrm{Hal}$ ini mengingat pewarnaan yang digunakan adalah pewarnaan cresyl violet, yang umum digunakan untuk mempelajari lapisan dan struktur neuron. Sedangkan mekanisme kerusakan pada mukosa maupun lapisanlapisan usus lainnya tidak bisa dinilai pada pewarnaan ini.

\section{SIMPULAN}

Berdasarkan penelitian ini dapat diambil kesimpulan bahwa lama trauma listrik berpengaruh pada sistem saraf traktus gastrointestinal ditinjau secara histopatologi.

\section{KONFLIK KEPENTINGAN}

Tidak terdapat konflik kepentingan dalam penulisan laporan penelitian ini.

\section{ETIKA PENELITIAN}

Penelitian ini telah mendapatkan persetujuan etik dari Komisi Etik, Fakultas Kedokteran Universitas Gadjah Mada, RSUP Dr Sardjito Yogyakarta, Indonesia, sebelum penelitian berjalan.

\section{PENDANAAN}

Penelitian ini dilakukan atas biaya pribadi tanpa dukungan sponsor. 


\section{KONTRIBUSI PENULIS}

Penulis menyatakan bahwa data analisa, mulai tahap penyusunan draft, isi, revisi artikel, sampai dengan pengajuan untuk persetujuan publikasi, seluruhnya dapat dipertanggungjawabkan.

\section{DAFTAR PUSTAKA}

1. Koumbourlis AC. Electrical injuries. Crit Care Med. 2002;30(11 Suppl):S424-S430.

2. Kym D, Seo DK, Hur GY, Lee JW. Epidemiology of electrical injury: Differences between lowand high-voltage electrical injuries during a 7 -year study period in South Korea. Scand J Surg. 2015;104(2):108-114.

3. Shih JG, Shahrokhi S, Jeschke MG. Review of Adult Electrical Burn Injury Outcomes Worldwide: An Analysis of Low-Voltage vs High-Voltage Electrical Injury. J Burn Care Res. 2017;38(1):e293-e298.

4. Martinez JA, Nguyen T. Electrical injuries. South Med J. 2000;93(12):1165-1168.

5. Buniak B, Reedy DW, Caldarella FA, Bales CR, Buniak L, Janicek D. Alteration in gastrointestinal and neurological function after electrical injury: a review of four cases. Am J Gastroenterol. 1999;94(6):1532-1536.

6. Esses SI, Peters WJ. Electrical burns; pathophysiology and complications. Can J Surg. 1981;24(1):11-14

7. Marques EG, Júnior GA, Neto BF, Freitas RA, Yaegashi LB, Almeida CE, et al. Visceral injury in electrical shock trauma: proposed guideline for the management of abdominal electrocution and literature review. Int J Burns Trauma. 2014;4(1):1-6.

8. Gulbransen BD, Sharkey KA. Novel functional roles for enteric glia in the gastrointestinal tract. Nat Rev Gastroenterol Hepatol. 2012;9(11):625-632.

9. Oommen V, Kanthakumar P. The gastrointestinal system: a piece of cake. Adv Physiol Educ. 2015;39(2):128.

10. Szurszewski JH. A 100-year perspective on gastrointestinal motility. Am J Physiol. 1998;274(3):G447-G453.

11. Gershon MD. Review article: serotonin receptors and transporters -- roles in normal and abnormal gastrointestinal motility. Aliment Pharmacol Ther. 2004;20 Suppl 7:3-14.

12. Li Z, Hao MM, Van den Haute C, Baekelandt V, Boesmans W, Vanden Berghe P. Regional complexity in enteric neuron wiring reflects diversity of motility patterns in the mouse large intestine. Elife. 2019;8:e42914.

13. Gershon MD. The enteric nervous system: a second brain. Hosp Pract (1995). 1999;34(7):3142.

14. Hao MM, Young HM. Development of enteric neuron diversity. J Cell Mol Med. 2009;13(7):1193-1210.

15. Uzün I, Akyildiz E, Inanici MA. Histopathological differentiation of skin lesions caused by electrocution, flame burns and abrasion. Forensic Sci Int. 2008;178(2-3):157161.

16. Bassotti G, Villanacci V, Fisogni S, Rossi E, Baronio P, Clerici C, et al. Enteric glial cells and their role in gastrointestinal motor abnormalities: introducing the neuro-gliopathies. World J Gastroenterol. 2007;13(30):4035-41.
17. Leibovici D, Shemer J, Shapira SC. Electrical injuries: current concepts. Injury. 1995;26(9):623-627.

18. Williams DB, Karl RC. Intestinal injury associated with low-voltage electrocution. J Trauma. 1981;21(3):246-250.

19. Narwanto I, Aswin S, Mustafa. Pengaruh Pemberian Etanol secara Kronik Terhadap Jumlah Sel Piramidal di Cal Hippocampus Tikus (Rattus Norvegicus) Remaja. Jurnal Anatomi Indonesia. 2007;2(1):29-33.

20. Rohmah IN, Sadad AR, Johan A. Perbedaan Jumlah Sel Nekrosis Sel Otak dan Nilai pH Darah Tikus Wistar pada Pemberian Formalin Peroral Dosis Bertingkat. Media Medika Muda. 2016;1(1):31-37.

21. Rizal S. Perbedaan Gambaran Histopatologi Otak Tikus Wistar Akibat Paparan Arus Listrik pada Media Air Tawar dan Air Laut [Skripsi]. Program Pendidikan Sarjana Kedokteran Universitas Diponegoro. 2014

22. Branday JM, DuQuesnay DR, Yeesing MT, Duncan ND. Visceral complications of electrical burn injury. A report of two cases and review of the literature. West Indian Med J. 1989;38(2):110-113

23. Sharma M, Kaundal P, Sharma P, Chaudhary R. Electric Current Causing Sigmoid Perforation: Case Report. Annals of International Medical and Dental Research. 2015;1(1):39-40.

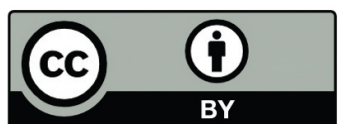

This work is licensed under a Creative Commons Attribution 